\title{
Eimeria tamimi sp. n. (Apicomplexa: Eimeriidae) from the rock hyrax (Procavia capensis jayakari) in central Saudi Arabia
}

\author{
Osama B. Mohammed ${ }^{1}$, Manei M. Aljedaie ${ }^{2,3}$, M. S. Alyousif ${ }^{2}$ and Nabil Amor ${ }^{1}$ \\ ${ }^{1}$ KSU Mammals Research Chair, Department of Zoology, College of Science, King Saud University, Riyadh, Saudi Arabia. \\ ${ }^{2}$ Department of Zoology, College of Science, King Saud University, Riyadh, Saudi Arabia. \\ ${ }^{3}$ Present address: Department of Biology, College of Science and Humanities, Prince Sattam Bin Abdulaziz University, Alkharj, \\ Saudi Arabia.
}

\begin{abstract}
Faecal samples from the rock hyrax (Procavia capensis jayakari Thomas) were collected from the Ibex Reserve in central Saudi Arabia. Eimerian oocysts, which are believed to represent a new species described here as Eimeria tamimi sp. n., were detected in 40 out of 93 samples. Oocysts were fully sporulated in $24-48$ hours at $25 \pm 2{ }^{\circ} \mathrm{C}$. Sporulated oocysts of E. tamimi sp. n. were ovoid, measuring 35-42 × 19-25 $\mu \mathrm{m}(39 \times 23 \mu \mathrm{m})$, a length/width ratio 1.5-2 (1.7). Oocyst wall was bilayered and measured $1.5 \mu \mathrm{m}$ in thickness. Micropyle, oocyst residuum and polar granules were not present. Sporocysts are elongate, measuring 12-18 $\times 9-12 \mu \mathrm{m}$ $(15 \times 10 \mu \mathrm{m})$, with a length/width ratio 1.1-1.8 (1.5) prominent Stieda bodies and sporocyst residuum. Experimental infection of two clinically healthy rock hyraxes with sporulated oocysts of E. tamimi sp. n. resulted in shedding unsporulated oocysts 5-10 days post infection. Partial sequences of $18 \mathrm{~S}$ ribosomal RNA (18S rDNA) and cytochrome C oxidase subunit 1 (COI) regions were amplified using the polymerase chain reaction (PCR) and sequenced. Phylogenetic analysis based on 18S rDNA using maximum likelihood (ML) and Bayesian inference (BI) methods revealed that E. tamimi sp. n. grouped with Eimeria quokka Barker, O'Callaghan et Beveridge, 1988, E. mundayi Barker, O'Callaghan et Beveridge, 1988, E. potoroi Barker, O'Callaghan et Beveridge, 1988 and E. gaimardi Barker, O'Callaghan et Beveridge, 1988 marsupials. Eimerian species have been regarded as a paraphyletic group and the present investigation confirmed the conflict between phenotypic traits, used widely in the classification of this group of parasites.
\end{abstract}

Keywords: coccidia, Howtat Bani Tamim, Hyracoidea, morphology, molecular characterisation.

The rock hyrax Procavia capensis (Pallas) (Mammalia: Hyracoidea), also known as dassie or rock rabbit, is a smallhoofed ungulate. It is neither lagomorph nor entirely rock dweller. Hyraxes are rodent-like in appearance, with a short neck, ears, and tail. Three genera of hyrax are known, the bush hyrax (Heterohyrax Gray), the rock hyrax (Procavia Storr), and the tree hyrax (Dendrohyrax Gray). The first two genera are terrestrial animals that live in groups among rocks and are active by day, whereas the third one is arboreal, solitary, and nocturnal (Shoshani 2005). All hyraxes feed on grasses and leaves; however, they may also feed on insects and lizards (Jones 1984, Feldhamer et al. 1999).

The phylogenetic relationships of the order Hyracoidea with other mammalian groups are not fully understood. Morphologically they are related to ungulates, but fossils of 30 million years ago indicated most of these hyraxes were large in size. The closest extant relatives of the Hyracoidea are Proboscidae (elephants) and Sirenia (manatees and dugongs) (Rohland et al. 2007, Kuntner et al. 2011, Meredith et al. 2011). The rock hyrax is distributed in the sub-Saharan and northern Africa as well as in the Middle East including Saudi Arabia (Skinner and Chimimba 2005, Butynski et al. 2015). Only two subspecies of $P$. capensis occur outside Africa, Procavia capensis jayakari Thomas, which is believed to occur in Saudi Arabia, and Procavia capensis syriaca Schreber, which occurs in the Levant including Syria, Jordan, and Palestine (Kingdon 1971, Harrison and Bates 1991, Kamal 1996). In Africa, the common subspecies Procavia capensis capensis (Pallas) is distributed throughout its range although other subspecies are recognised based on morphological characteristics and pelage colour differences (Springer 2003, Seiffert 2007).

Several helminths and protozoan parasites have been reported from the rock hyrax. Hall (1916) listed the following nematodes as parasitising P. capensis, Crossophorus eouaris Hemprich et Ehrenberg, 1828 (Ascaridida), Crossophorus tentaculatus Hemprich et Ehrenberg, 1828, Crossophorus collaris Hemprich et Ehrenberg, 1828, Oxy-

Address for correspondence: Osama B. Mohammed, KSU Mammals Research Chair, Department of Zoology, College of Science, King Saud University, Riyadh 11451, Saudi Arabia. E-mail: obmkkwrc@yahoo.co.uk, Phone: 00966504140713 
uris flagellum Ehrengerg, 1828 (Oxyurida), Oxyuris pugio Ehrengerg, 1828 and Physaloptera spirula Hemprich et Ehrenberg, 1828 (Spirurida).

The tapeworms Inermicapsifer beveridgei Schmidt et Wertheim, 1988 and Inermicapsifer hyracis (Rudolphi, 1810) (Cestoidea: Anoplocephalidae) were detected from $P$. capensis (Hyracoidea) in Japan and Middle East (Schmidt and Wertheim 1988, Saitoh et al. 2004). The nematode, Grassenema procaviae Petter, 1959, has also been described from the rock hyrax in Japan (Saitoh et al. 2004).

Few protozoan parasites have been reported from Hyracoidea: only two species of Eimeria Schneider, 1875 (Apicomplexa: Eimeriorina: Eimeriidae) have been reported from Procavidae: Eimeria dendrohyracis van de Berghe et Chardome, 1953 and Eimeria dorsalisi van de Berghe et Chardome, 1962. The first species was described from the Eastern tree hyrax (Dendrohyrax arboreus [Smith]) whereas the latter was described from the Western tree hyrax (Dendrohyrax dorsalis [Fraser]). Apart from those reports, Saitoh et al. (2004) reported E. dendrohyracis from a captive rock hyrax ( $P$. capensis) in Guma Safari Park, Japan. Toxoplasma gondii (Nicolle et Manceaux, 1908) was reported from $P$. capensis in Japan (El-Dakhly et al. 2013). Cryptosporidium muris Tyzzer, 1907 has been reported from experimentally infected $P$. capensis (Xiao et al. 1999).

From the order Hyracoidea, only two species of Eimeria have been reported and none has been described from the rock hyrax (P. capensis) apart from single report of $E$. dendrohyracis from Japan based on morphological appearance (Saitoh et al. 2004). Here a new species of Eimeria is described from $P$. capensis jayakari based on morphological as well as molecular characteristics using both partial $18 \mathrm{~S}$ rDNA and COI genes.

\section{MATERIALS AND METHODS}

Faecal samples from 93 rock hyrax (Procavia capensis jayakari) were collected from the Ibex Reserve in Howtat Bani Tamim, south of Riyadh, central Saudi Arabia. The samples were moist when they were collected indicating that they were fresh. Oocysts were left in shallow layer of $2.5 \% \mathrm{~K}_{2} \mathrm{Cr}_{2} \mathrm{O}_{7}$ to allow to sporulate and examined daily to check the progress of sporulation. In the laboratory, a small amount of the faecal sample was ground and strained through a sieve and underwent flotation technique using saturated sugar solution (Anonymous 1986). Oocysts detected were examined microscopically and measured using eyepiece fitted calibrated micrometer. Measurements of the sporulated oocysts, the sporocysts and the wall thickness are given in micrometres $(\mu \mathrm{m})$. Oocysts were left in a shallow layer of $2.5 \%$ $\mathrm{K}_{2} \mathrm{Cr}_{2} \mathrm{O}_{7}$ allowing sporulation to take place and the suspension was examined on daily basis to check the progress of the sporulation process (Mohammed and Hussein 1992). Digital images of unsporulated and sporulated oocysts were taken using a digital camera attached to the microscope (Nikon, DP 72, Tokyo, Japan).

\section{Experimental infection}

Three two-month-old rock hyraxes were obtained from nearby the Ibex Reserve. The animals were brought to the Department of Zoology animal facility. Animals were checked for the presence of gastrointestinal parasites, particularly for eimerian oocysts for a period of 15 days prior to the experiment and proved to be negative. Clean food and water were provided ad libitum. Thoroughly washed sporulated oocysts of the new species of Eimeria were administered using a stomach tube to two animals and the third one was left as an uninfected control. The inoculum contained 5,000 sporulated oocysts and each experimental animal received this amount. Daily faecal samples were collected from the animals fed sporulated oocysts and examined microscopically. When oocysts started to show in faeces a modified McMaster technique was used to quantify the number of oocysts per gram (opg) of faeces (Anonymous 1986).

\section{DNA extraction and Polymerase Chain Reaction}

Sporulated oocysts were purified by washing in distilled water for 3-5 times till the supernatant was clear and free of potassium dichromate. Purified oocysts were subjected to DNA extraction using the technique outlined in Zhao et al. (2001) using the method involving CTAB buffer treatment with slight modification. Purified oocysts were treated with sodium hypochlorite and Cetyl-Trimethyl Ammonium Bromide (CTAB) buffer (2\% w/v CTAB, 1.4 M NaCl, 0.2\% b-mercaptoethanol, 20 mM EDTA, 100 $\mathrm{mM}$ TRIS) was added. DNA extraction from the lysate was completed using QiaAmp DNA Micro extraction kit (Qiagen, Hilden, Germany).

Extracted genomic DNA was subjected to PCR amplification using primers which amplify part of the $18 \mathrm{~S}$ rDNA gene (636 bp) with the forward primer F1E and reverse primer R2B (Orlandi et al. 2003). Partial COI gene ( $650 \mathrm{bp}$ ) was also amplified using the primers cocci-CO1F and cocci-CO1R as described by Ogedengbe et al. (2011).

The Polymerase Chain Reaction (PCR) was set up in $25 \mu 1$ using Bioline Buffer (Bioline, London, UK) containing $200 \mu \mathrm{M}$ concentrations each of dNTPs. The reaction mixture was adjusted to a final concentration of $2 \mathrm{mM} \mathrm{MgCl}_{2}$ and $0.2 \mu \mathrm{M}$ concentrations of each primer. DNA Taq polymerase (Bioline) was added to the PCR mixture. The PCR amplifications were performed in a Multigene $^{\mathrm{TM}}$ thermocycler (Labnet International, Inc., Edison, NJ, USA). The amplification program began with one cycle of 2 minutes at $94^{\circ} \mathrm{C}$ as an initial denaturation step. The cycling conditions consisted of 35 cycles of denaturation at $94^{\circ} \mathrm{C}$ for $30 \mathrm{~s}$, annealing at $\left(50^{\circ} \mathrm{C}\right.$ for $18 \mathrm{~S} \mathrm{rDNA} ; 52^{\circ} \mathrm{C}$ for COI) for $30 \mathrm{~s}$, and primer extension at $72^{\circ} \mathrm{C}$ for $30 \mathrm{~s}$. A final extension at $72^{\circ} \mathrm{C}$ for 7 min was allowed, and followed by keeping at $4^{\circ} \mathrm{C}$.

PCR products were visualised using a gel documentation system and digital images of the PCR product were obtained. PCR products were cut from the gel and purified using Isolate II PCR and Gel purification kit (Bioline) and sequenced using Macrogen sequencing facility (Macrogen Inc, Seoul, South Korea).

\section{Data analysis}

Phylogenetic relationships between the new species and related Eimeria spp. were inferred using 18S rDNA, and COI loci available in GenBank database. Seaview 3.2 (Galtier et al. 1996) was used to perform multiple alignments for each genetic marker. COI sequences were translated into amino acids to check for possible amplification of pseudogenes. Representative sequences of the Eimeriidae available in GenBank were included in both datasets (18S rDNA and COI) (Table 1). 

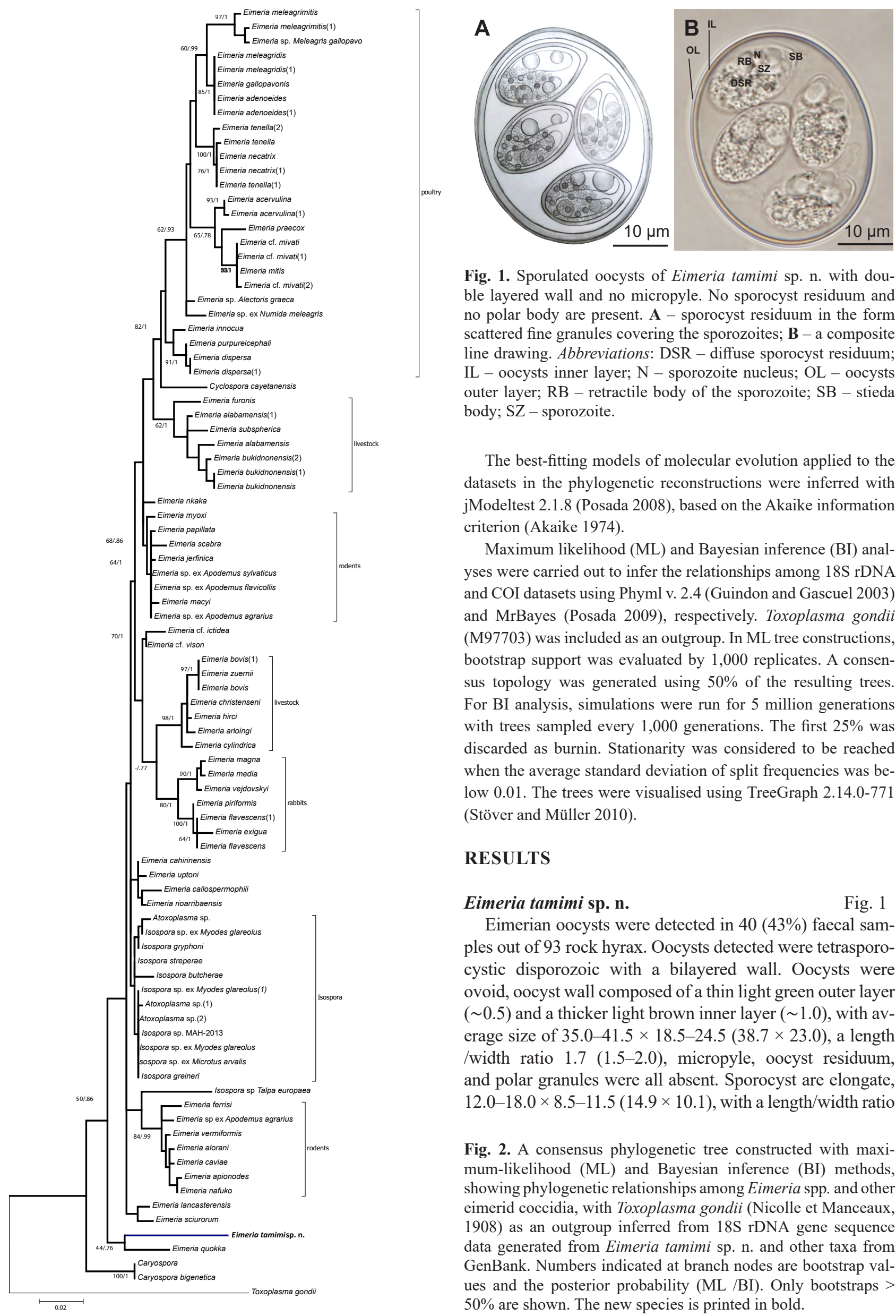

Fig. 1. Sporulated oocysts of Eimeria tamimi sp. n. with double layered wall and no micropyle. No sporocyst residuum and no polar body are present. A - sporocyst residuum in the form scattered fine granules covering the sporozoites; $\mathbf{B}$ - a composite line drawing. Abbreviations: DSR - diffuse sporocyst residuum; IL - oocysts inner layer; $\mathrm{N}$ - sporozoite nucleus; OL - oocysts outer layer; RB - retractile body of the sporozoite; SB - stieda body; SZ - sporozoite.

The best-fitting models of molecular evolution applied to the datasets in the phylogenetic reconstructions were inferred with jModeltest 2.1.8 (Posada 2008), based on the Akaike information criterion (Akaike 1974).

Maximum likelihood (ML) and Bayesian inference (BI) analyses were carried out to infer the relationships among 18S rDNA and COI datasets using Phyml v. 2.4 (Guindon and Gascuel 2003) and MrBayes (Posada 2009), respectively. Toxoplasma gondii (M97703) was included as an outgroup. In ML tree constructions, bootstrap support was evaluated by 1,000 replicates. A consensus topology was generated using $50 \%$ of the resulting trees. For BI analysis, simulations were run for 5 million generations with trees sampled every 1,000 generations. The first $25 \%$ was discarded as burnin. Stationarity was considered to be reached when the average standard deviation of split frequencies was below 0.01 . The trees were visualised using TreeGraph 2.14.0-771 (Stöver and Müller 2010).

\section{RESULTS}

\section{Eimeria tamimi sp. n.}

Fig. 1

Eimerian oocysts were detected in 40 (43\%) faecal samples out of 93 rock hyrax. Oocysts detected were tetrasporocystic disporozoic with a bilayered wall. Oocysts were ovoid, oocyst wall composed of a thin light green outer layer $(\sim 0.5)$ and a thicker light brown inner layer $(\sim 1.0)$, with average size of $35.0-41.5 \times 18.5-24.5(38.7 \times 23.0)$, a length /width ratio 1.7 (1.5-2.0), micropyle, oocyst residuum, and polar granules were all absent. Sporocyst are elongate, $12.0-18.0 \times 8.5-11.5(14.9 \times 10.1)$, with a length/width ratio

Fig. 2. A consensus phylogenetic tree constructed with maximum-likelihood (ML) and Bayesian inference (BI) methods, showing phylogenetic relationships among Eimeria spp. and other eimerid coccidia, with Toxoplasma gondii (Nicolle et Manceaux, 1908 ) as an outgroup inferred from 18S rDNA gene sequence data generated from Eimeria tamimi sp. n. and other taxa from GenBank. Numbers indicated at branch nodes are bootstrap values and the posterior probability (ML /BI). Only bootstraps > $50 \%$ are shown. The new species is printed in bold. 


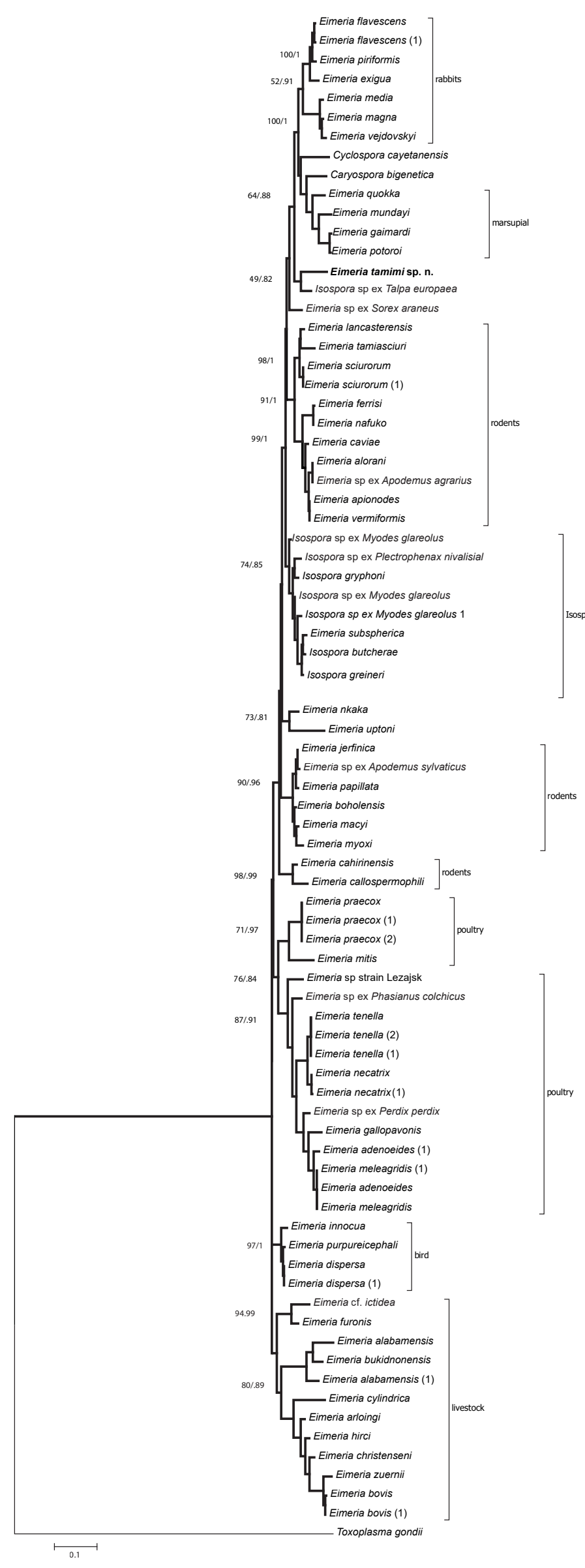

1.1-1.8 (1.5), a Stieda body was present, a prominent sporocyst residuum and retractile granules (Fig. 1). Sporocyst residuum is composed of small granules dispersed between sporozoites. Sporozoites are sausage-shaped with larger and smaller refractile bodies. Species description was performed according to Duszynski and Wilber (1997).

Experimental animals started shedding unsporulated oocysts of Eimeria tamimi sp. n. five days post infection. Shedding of the oocysts continued for a period of another five days till they ceased shedding oocysts. Oocyst output was 3,950 opg on the first day and continued to rise till it peaked on the third day and showed 9,250 opg then declined to $3,050 \mathrm{opg}$ on the fifth day. No oocysts were recovered from faeces after the fifth day of infection. The animals did not show any signs of diarrhoea or soft droppings which indicated that the parasite is of no remarkable pathogenicity.

\section{Taxonomic summary}

Type host: Rock hyrax (Procavia capensis jayakari).

Other hosts: Unknown.

Type locality: Howtat Bani Tamim (234ㄴ $48^{\prime \prime N}$; 465'55"E) Ibex Reserve, Saudi Arabia.

Other localities: Unknown.

The site of infection: Unknown, oocysts detected in faeces. Prevalence: Oocysts detected in 40 out of 93 rock hyraxes (43\%). Prepatent period: Five days.

Patent period: Five days.

Sporulation time: 24 to 48 hours.

Material deposited: Photoneosyntype (see Duszynski 1999 for terminology) deposited at the Museum of the Department of Zoology, College of Science, King Saud University (Acc. No. 931). Sporulated and unsporulated oocysts in $10 \%$ formalin were kept at the same collection together with the photoneosyntype. DNA sequences have been deposited in GenBank under accession numbers MK075988 and MK075989 for the 18S rDNA and COI loci, respectively.

E ty m ology: The specific name of Eimeria tamimi sp. n. was derived from the name of the tribe which inhabits Howtat Bani Tamim the area where the host occurs.

\section{Remarks}

The oocysts described from the rock hyrax (P. capensis jayakari) in the present study are different from those described from the eastern (Dendrohyrax arboreus) and western tree (Dendrohyrax dorsalis) hyrax. Oocysts of Eimeria dendrohyracis from $D$. arboreus are elliptical and measure $23.8-26.8 \times 16.8-18.2 \mu \mathrm{m}$ and the sporocyst measures 7.0-8.4 $\mu \mathrm{m}$. Oocysts of Eimeria dorsalisi from the western tree hyrax (D. dorsalis) are spherical and measure 19

Fig. 3. A consensus phylogenetic tree constructed with maximum-likelihood (ML) and Bayesian inference (BI) methods, showing phylogenetic relationships among Eimeria spp. and other eimerid coccidia, with Toxoplasma gondii (Nicolle et Manceaux, 1908) (outgroup) inferred from the COI sequences data generated from Eimeria tamimi sp. n. and other taxa from GenBank. Numbers indicated at branch nodes are bootstrap values and the posterior probability (ML/BI). Only bootstraps $>50 \%$ are shown. The new species is printed in bold. 


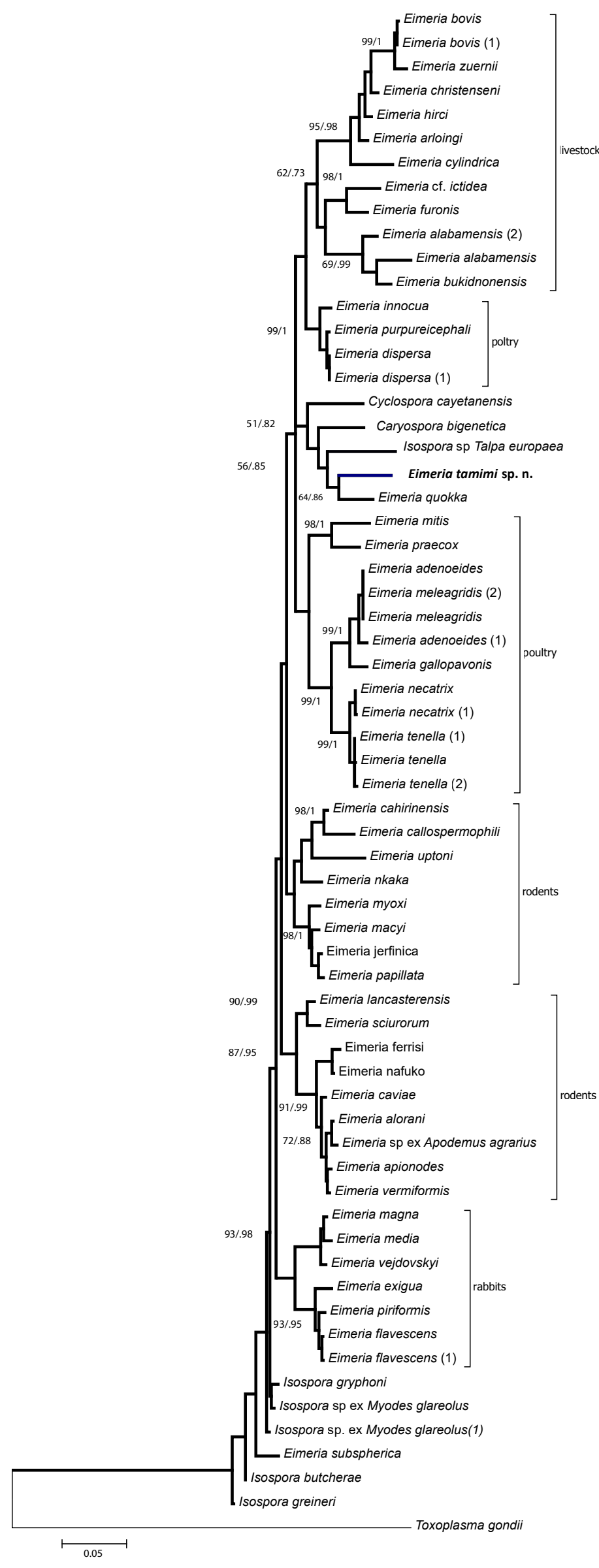

in diameter (Table 2). The prepatent period, as well as the patent period of the parasite, were found to be 5 days. The parasite did not appear to be associated with pathology since the faecal material voided by infected animals did not show any sign of diarrhoea. The control animal remained negative for oocysts till the end of the experiment.

\section{Molecular data analyses}

A PCR product of $636 \mathrm{bp}$ was successfully amplified from the $18 \mathrm{~S}$ rDNA region of E. tamimi sp. n. and sequenced. A fragment of a length of $650 \mathrm{bp}$ was also successfully amplified and sequenced from the COI of the mitochondrial genome. PCR products from two isolates produced identical sequences for the $18 \mathrm{~S}$ rDNA and COI. Final alignment of 598 bp (18S rDNA) and 583 bp (COI) were used for the phylogenetic analyses. 18S rDNA and COI datasets included 92 and 79 sequences, respectively. Edited sequences input files were concatenated resulting in the inclusion of 67 sequences and 1,184 characters.

The optimum evolutionary models selected by jModelTest were GTR + I, HKY + I and HKY for 18S rDNA, COI and concatenated datasets, respectively. Both phylogenetic analyses showed similar overall topologies; however, the position of several taxa varies when comparing the different trees. Node support values within the text consist of ML bootstrap values and Bayesian posterior probabilities.

In all trees, species of Eimeria appeared as paraphyletic with several clades characterised by well-defined spectrum of host taxa (rodents, rabbits, livestock and poultry). Other genera included in the analysis, such as Isospora Schneider, 1881, appeared polyphyletic. For all observed clades, the range of node support was higher in the Bayesian analysis.

Eimeria tamimi did not fall within one of these monophyletic clades. The $18 \mathrm{~S}$ rDNA tree (Fig. 2) indicates that E. tamimi forms a clade with E. quokka, E. mudayi, E. potoroi and E. gaimardi of the marsupials. However, in the COI tree (Fig. 3), E. tamimi appeared to belong to a different clade including one of the paraphyletic Isospora (Isospora sp. ex Talpa europaea Linnaeus). The concatenated tree showed a clade including E. tamimi, E. quokka, Isospora sp. ex T. europaea, Cyclospora cayetanensis Ortega, Gilman et Sterling, 1994 and Caryospora bigenetica Wacha et Christiansen, 1982, with a high bootstrap separating $E$. tamimi from the marsupial eimerian parasites $(E$. quakka, E. mudayi, E. potoroi and E. gaimardi) (Fig. 4).

This analysis showed that several taxa require revision regarding their phylogenetic position. Although the major clades within Eimeria were well supported, especially in

Fig. 4. A consensus phylogenetic tree constructed with maximum-likelihood (ML) and Bayesian inference (BI) methods, showing phylogenetic relationships among Eimeria spp. and other eimerid coccidia, with Toxoplasma gondii (Nicolle et Manceaux, 1908) (outgroup) inferred from concatenated sequences from both $18 \mathrm{~S}$ rDNA and COI genes generated from Eimeria tamimi sp. n. and other taxa from the GenBank. Numbers indicated at branch nodes are bootstrap values and the posterior probability (ML /BI). Only bootstraps $>50 \%$ are shown. E. tamimi sp. n. is printed in bold. 
Table 1. Taxa and their GenBank accession numbers used in the present analyses.

\begin{tabular}{|c|c|c|c|c|c|}
\hline Species & $\begin{array}{l}18 S \text { rRNA Gen- } \\
\text { Bank Acces- } \\
\text { sion number }\end{array}$ & $\begin{array}{l}\text { COX1 } \\
\text { GenBank } \\
\text { Accession } \\
\text { number }\end{array}$ & $\begin{array}{l}\text { Eimeria meleagridis } 1 \\
\text { Eimeria meleagrimitis } \\
\text { Eimeria meleagrimitis } 1 \\
\text { Eimeria mitis }\end{array}$ & $\begin{array}{l}\text { HG793040 } \\
\text { KC305191 } \\
\text { KC305197 } \\
\text { FR775303 }\end{array}$ & $\begin{array}{c}\text { HG793047 } \\
- \\
- \\
\text { FR796699 }\end{array}$ \\
\hline E. tamimi sp. n. & MK075988 & MK075989 & Eimeria mundayi & MK182526 & MK202808 \\
\hline Atoxoplasm $\mathrm{s} p$ & AY331569 & - & Eimeria myoxi & JF304148 & JQ993696 \\
\hline Atoxoplasma sp. 1 & AY331571 & - & Eimeria nafuko & JQ993665 & JQ993708 \\
\hline Atoxoplasma sp. 2 & AY331566 & - & Eimeria necatrix & KT184349 & KT184349 \\
\hline Caryospora & KJ651445 & - & Eimeria necatrix 1 & EU025108 & JN022588 \\
\hline Caryospora bigenetica & KT184331 & KP658102 & Eimeria nkaka & JQ993651 & JQ993697 \\
\hline Cyclospora cayetanensis & KX618190 & MG831586 & Eimeria papillata & KT184350 & KT184377 \\
\hline Eimeria acervulina & DQ538351 & - & Eimeria piriformis & HQ173836 & JQ993698 \\
\hline Eimeria acervulina 1 & U67115 & - & Eimeria potoroi & MK182527 & MK202807 \\
\hline Eimeria adenoeides & FR745914 & FR84620 & Eimeria praecox & KT184352 & KT184378 \\
\hline Eimeria adenoeides 1 & $\mathrm{KC} 305172$ & FR846202 & Eimeria praecox 1 & - & JQ659301 \\
\hline Eimeria alabamensis & AF291427 & KU351690 & Eimeria praecox 2 & - & KX094943 \\
\hline Eimeria alabamensis 1 & AB769554 & KT184335 & Eimeria purpureicephali & KU140597 & KU140598 \\
\hline Eimeria alorani & KU192970 & JQ993701 & Eimeria quokka & KF225636 & KF225637 \\
\hline Eimeria apionodes & KU192973 & KU255441 & Eimeria rioarribaensis & LC371915 & - \\
\hline Eimeria arloingi & KX845686 & KX857470 & Eimeria scabra & AF279668 & - \\
\hline Eimeria boholensis & - & MH350860 & Eimeria sciurorum & KT360994 & KT361027 \\
\hline Eimeria bovis & KT184336 & KT184372 & Eimeria sciurorum 1 & - & KT361025 \\
\hline Eimeria bovis 1 & KU641156 & KU351696 & Eimeria sp. Alectoris graeca & HM070378 & HM117020 \\
\hline Eimeria bukidnonensis & AB769600 & KU351700 & Eimeria sp. ex Apodemus agrarius & JQ993660 & JQ993702 \\
\hline Eimeria bukidnonensis 1 & AB769596 & - & Eimeria sp. ex Apodemus agrarius 1 & KU192962 & - \\
\hline Eimeria bukidnonensis 2 & AB769595 & - & Eimeria sp. ex Apodemus flavicollis & KU192939 & - \\
\hline Eimeria cahirinensis & JQ993647 & JQ993687 & Eimeria sp. ex Apodemus sylvaticus & KU192943 & JQ993706 \\
\hline Eimeria callospermophili & MG595728 & JN021270 & Eimeria sp. ex Numida meleagris & KJ547707 & - \\
\hline Eimeria caviae & JQ993649 & JQ993689 & Eimeria sp. ex Perdix perdix & - & KJ547709 \\
\hline Eimeria cf ictidea & MF860827 & MF860823 & Eimeria sp. ex Phasianus colchicus & - & KJ547708 \\
\hline Eimeria cf. mivati & FJ236378 & - & Eimeria sp. ex Sorex araneus & - & JQ993710 \\
\hline Eimeria cf. mivati 1 & FJ236377 & - & Eimeria sp. Meleagris gallopavo & HM117014 & - \\
\hline Eimeria cf. mivati 2 & FJ236376 & - & Eimeria sp. strain Lezajsk & - & MG595960 \\
\hline Eimeria cf. vison & MG011726 & - & Eimeria subspherica & LC271171 & KU351704 \\
\hline Eimeria christenseni & KX857468 & KX845684 & Eimeria tamiasciuri & - & KT184375 \\
\hline Eimeria cylindrica & KU641163 & KU35170 & Eimeria tenella & EU025113 & EU025109 \\
\hline Eimeria dispersa & KT184338 & KT184338 & Eimeria tenella 1 & DQ136180 & FJ236396 \\
\hline Eimeria dispersa 1 & HG793048 & HG793028 & Eimeria tenella 2 & DQ136184 & FJ236385 \\
\hline Eimeria exigua & KT360996 & JQ993691 & Eimeria uptoni & KU192953 & KU216026 \\
\hline Eimeria ferrisi & KT360995 & KT361028 & Eimeria vejdovskyi & HQ173838 & JQ993699 \\
\hline Eimeria flavescens & JX406873 & JQ993692 & Eimeria vermiformis & KT184355 & KT184355 \\
\hline Eimeria flavescens 1 & HQ173830 & КР025693 & Eimeria zuernii & KT184356 & KT184356 \\
\hline Eimeria furonis & AB329724 & MF795598 & Isospora butcherae & KY801685 & KY801687 \\
\hline Eimeria gaimardi & MK182525 & MK202809 & Isospora greineri & KR108298 & KR108298 \\
\hline Eimeria gallopavonis & KT184343 & KT184343 & Isospora gryphoni & KF854254 & - \\
\hline Eimeria hirci & KX845685 & KX857469 & Isospora sp. ex Microtus arvalis & MH698573 & - \\
\hline Eimeria innосиа & HG793045 & HG793049 & Isospora sp. ex Plectrophenax nivalis & - & MH698551 \\
\hline Eimeria jerfinica & KU192975 & KU216033 & Isospora sp. MAH 2013 & KF648870 & - \\
\hline Eimeria lancasterensis & KT368144 & KT361043 & Isospora sp. ex Myodes glareolus & MH698575 & MH698560 \\
\hline Eimeria macyi & MK284237 & MK284238 & Isospora sp. ex Myodes glareolus 1 & MH698576 & MH698561 \\
\hline Eimeria magna & JQ071391 & JQ993695 & Isospora sp. ex Talpa europaea & JQ993669 & JQ993712 \\
\hline Eimeria media & HQ173834 & HQ173884 & Isospora streperae & KJ634021 & - \\
\hline Eimeria meleagridis & HG793039 & HG793046 & Toxoplasma gondii & M97703 & HM771690 \\
\hline
\end{tabular}

the case of the Bayesian analysis, the relationships between different sister clades remain unresolved.

\section{DISCUSSION}

Rock hyrax is an omnivore and it primarily feeds on grass, insects, bird eggs and lizards (Jones 1984, Feldhamer et al. 1999). The distinctive morphological characters and the dimensions of the oocysts described from the rock hyrax (Procavia capensis jayakari) showed that this species is distinct and hitherto undescribed. Oocysts measured $35.0-41.5 \times 18.5-24.5 \mu \mathrm{m}(38.7 \times 23) \mu \mathrm{m}$, with a length/ width ratio of $1.5-2.0(1.7)$. It lacks the micropyle and

the oocyst residual body. It was morphologically different from the Eimeria dendrohyracis described from the Eastern tree hyrax (Dendrohyrax arboreus) which measured 23.8-26.8 $\times 16.8-18.2 \mu \mathrm{m}$ in dimension. Furthermore, it was also different from the spherical oocysts of Eimeria dorsalisi described from the Western tree hyrax (Dendrohyrax dorsalis) which measures 19.0 in diameter (van de Berghe and Chardome 1953, 1962). Sporocysts of E. dorsalisi are spherical and measure 9.5. Hence based on these morphological characters and distinctiveness from $E$. dorsalisi and E. dendrohyracis the species recovered from the rock hyrax was described as Eimeria tamimi sp. n. 
Table 2. Morphological differences between Eimeria tamimi sp. n. and other eimerian species reported from the members of the family Procavidae.

\begin{tabular}{llll}
\hline Eimerian species & Type host & Oocysts shape, size features & Sporocyst size
\end{tabular}

The prepatent and patent periods of E. tamimi was also determined for the first time in the type host of the parasite. The infected animals shed the oocysts for a short period of time which was 5 days. The prepatent period of 5 days was probably enough time for the parasite to produce unsporulated oocysts of E. tamimi (see Long 1990). This could possibly be the case in the wild unless animals concentrate in large densities in a small area as the case of Eimeria impalae Prasad et Narayan, 1963 in South Africa (Bigalke 1966).

As reported previously (Morrison et al 2004, Yabsley and Gibbs 2006, Kvičerová and Hypša 2013) Eimeria is clearly a paraphyletic group. In this study, E. tamimi falls in a clade including species of the Eimeriidae assigned to as different genera (e.g., Caryospora Leger, 1904, Cyclospora Schneider, 1881, Isopora Schneider, 1881). This result confirmed the conflict between phenotypic traits, used widely in the classification of eimirians, and phylogenetic relationships.

Although major clades within Eimeria support their host specificity clustering, it does not stem from a cophylogenetic process. Kvičerová and Hypša (2013) found that 11 eimerian species isolated from the genus Apodemus Kaup cluster in four different clades. They suggested an adaptation (ecology, physiology, etc.) as explanation to the observed patterns rather than host-parasite co-speciation. Comparison of the accuracy of ML and BI is problematic because these methods are implemented in different programs. However, several study estimated that the BI generally fares better than the ML approach in accuracy (Beerli 2006).

It is probably that eimerian parasites of the rock hyrax evolved with their host and therefore it is different to any related eimerian parasites and even eimerian parasites from related hosts. Sirenia and Proboscidea are phylogenetically related to the Hyracoidea (Rohland et al. 2007, Kuntner et al. 2011, Meredith et al. 2011). However, there is no named eimerian parasite described from the Proboscidea and only three species have been described from the Sirenia, namely, Eimeria manatus Upton, Odell, Bossart et Walsh, 1989, Eimeria nodulosa Upton, Odell, Bossart et Walsh, 1989 (from the Florida manatee, Trichechus manatus latirostris Linnaeus) and Eimeria trichechi Lainson, Naiff, Best et Shaw, 1983 (from the Amazonian manatee, Trichechus inunguis) (Lainson et al. 1983, Upton et al. 1989). These coccidia are far much smaller in size compared to the eimerian species reported in the present study. Eimeria manatus measures 10.5-13.5 × 9.0-13.5 $\mu \mathrm{m}$ (11.8 $\times 10.5 \mu \mathrm{m})$, whereas Eimeria nodulosa measures 14.5$17.5 \times 13.0-16.0 \mu \mathrm{m}(15.6 \times 14.7 \mu \mathrm{m})$, and E. trichechi measures $13.4 \times 13.3 \mu \mathrm{m}$. All of them lack the micropyle, oocysts residuum, and polar body. All has sporocyst residuum and Stieda body with the exception of E. trichechi. It is likely that the lack of the Stieda body could be an artefact and it is a feature of mammalian eimerian species. Eimeria dorcadis Mantovani, 1966 was first described by Mantovani (1966) and the original description was devoid of Stieda body. Mohammed et al. (2012) redescribed the species with a visible Stieda body which goes well with the findings from all mammalian eimerian parasites which possess Stieda body. Therefore, it may be likely that reinvestigating of $E$. trichechi may result in demonstrating the presence of Stieda body and also investigating their phylogenetic relationship with relevant eimerian parasites.

Eimeria tamimi is the first coccidia reported from the rock hyrax (P. capensis jayakari). The prepatent and patent periods of this eimerian parasite have also been determined for the first time. Molecular data support the identity validity of E. tamimi as a new species and indicate its relationship with some other eimerian species.

Acknowledgements. This work was financially supported by Researchers Supporting project number (RSP-2019/94), King Saud University, Riyadh, Saudi Arabia.

\section{REFERENCES}

Akaike H. 1974: A new look at the statistical model identification. In: J.S. Simonoff, Selected Papers of Hirotugu Akaike. Springer, New York, pp. 215-222.

AnONymous 1986: Manual of Veterinary Parasitological Laboratory Techniques. Technical Bulletin, No. 18, Ministry of Ag- riculture, Forestry and Fisheries, Great Britain. Her Majesty's Stationary Office, London, 118 pp.

BeErli P. 2005: Comparison of Bayesian and maximum-likelihood inference of population genetic parameters. Bioinformatics 22: 341-345. 
Bigalke R.D. 1966: Coccidiosis in antelopes. Fauna and Flora of Transvaal 17: 38-42.

Butynski T., Hoeck H., Koren L., De Jong Y.A. 2015: Procavia capensis. The IUCN Red List of Threatened Species. IUCN. 2015: e.T41766A21285876.

DUSZYNSKI D.W. 1999: Revisiting the code: clarifying name-bearing type for photomicrographs of Protozoa. J. Parasitol. 85: 769-770.

Duszynski D.W., Wilber P.G. 1997: A guideline for the preparation of species description in the Eimeriidae. J. Parasitol. 83: 333-336.

El-Dakhly K.M., El-Habashi N., El-Nahass E., Sakai H., Yanai T. 2013: Toxoplasmosis in the Eastern Grey Kangaroo, Macropus giganteus and the Cape Hyrax, Procavia capensis in Japan. Pak. Vet. J. 33: 529-531.

Feldhamer G.A., Drickamer L.C., Vessey S.H., Merritt J.F. 1999: Mammalogy. Adaptation, Diversity, and Ecology. WCB McGraw-Hill, Boston. xii+563 pp.

Galtier N., Gouy M., Gautier C. 1996: SEAVIEW and PHYLO_WIN: two graphic tools for sequence alignment and molecular phylogeny. Bioinformatics 12: 543-548.

Guindon S., Gascuel O. 2003: A simple, fast, and accurate algorithm to estimate large phylogenies by maximum likelihood. Syst. Biol. 52: 696-704.

Hall M.C. 1916: Nematode parasites of mammals of the orders Rodentia, Lagomorpha, and Hyracoidea. Proc. U.S. Natl. Mus. 50: $1-258$.

Harrison D.L., Bates P.J. 1991: The Mammals of Arabia. Second edition. Harrison Zoological Museum, London, 354 pp.

JoNES C. 1984: Tubulidentates, proboscideans, and hyracoideans. In: S. Anderson and J.K. Jones Jr. (Eds), Orders and Families of Recent Mammals of the World. John Wiley and Sons, New York, pp. 523-535.

Kamal K.B. 1996: Distribution, morphology, and behavior of rock hyrax (Procavia capensis) in the western region of Saudi Arabia. P. Zool. Soc. Lond. A.R. Egypt 27: 75-80.

Kingdon J. 1971: East African Mammals. Vol. I. Academic Press, London, $446 \mathrm{pp}$.

Kuntner M., May-Collado L.J., Agnarsson I. 2011: Phylogeny and conservation priorities of afrotherian mammals (Afrotheria, Mammalia). Nor. Acad. Sci. Lett. 40: 1-15.

KviČEROVÁ J., HyPŠA V. 2013: Host-parasite incongruences in rodent Eimeria suggest significant role of adaptation rather than cophylogeny in maintenance of host specificity. PLoS ONE 8: e63601.

Lainson R., Naiff R.D., Best R.C., Shaw J.J. 1983: Eimeria trichechi $\mathrm{sp}$. n. from the Amazonian manatee, Trichechus inunguis (Mammalia: Sirenia). Syst. Parasitol. 5: 287-289.

Long P. 1990: Coccidiosis of Man and Domestic Animals. CRC Press, Boca Raton, 356 pp.

Mantovani A. 1966: Eimeria dorcadis sp. n. (Protozoa: Eimeriidae) parasite di Gazella dorcas (L.). Parassitologia 8: 13-15.

Meredith R.W., JanečKa J.E., Gatesy J., Ryder O.A., Fisher C.A., Teeling E.C., Goodbla A., Eizirik E., Simão T.L., Stadler T., RABosky D.L. 2011: Impacts of the Cretaceous terrestrial revolution and KPg extinction on mammal diversification. Science 334: 521-524.

Mohammed O.B., Hussein H.S. 1992: Eimeria idmii sp. n. (Apicomplexa: Eimeriidae) from the Arabian mountain gazelle, Gazella gazella, in Saudi Arabia. J. Helminthol. Soc. Wash. 59: $120-124$.

Mohammed O.B., Alagaili A.N., Omer S.A. 2012: Redescription of Eimeria dorcadis Mantovani, 1966 (Apicomplexa:
Eimeriidae) from the dorcas gazelle (Gazella dorcas) in Saudi Arabia. Folia Parasitol. 59: 27-31.

Morrison D.A., Bornstein S., Thebo P., Wernery U., Kinne J., Mattsson, J.G. 2004: The current status of the small subunit rRNA phylogeny of the coccidia (Sporozoa). Int. J. Parasitol. 34: 501-514.

Ogedengbe J.D., Hanner R.H., Barta J.R. 2011: DNA barcoding identifies Eimeria species and contributes to the phylogenetics of coccidian parasites (Eimeriorina, Apicomplexa, Alveolata). Int. J. Parasitol. 41: 843-850.

Orlandi P.A., Carter L., Brinker A.M., Da Silva A.J., Chu D.M., LAmpel K.A., Monday S.R. 2003: Targeting single-nucleotide polymorphisms in the $18 \mathrm{~S}$ rRNA gene to differentiate Cyclospora species from Eimeria species by multiplex PCR. Appl. Environ. Microbiol. 69: 4806-4813.

PosaDA D. 2008: jModelTest: phylogenetic model averaging. Mol. Biol. Evol. 25: 1253-1256.

Posada D. 2009: Selection of models of DNA evolution with jModelTest. Methods Mol. Biol. 537: 93-112.

Rohland N., Malaspinas A., Pollack J.L., Slatkin M., Matheus P., Hofreiter M. 2007: Proboscidean mitogenomics: chronology and mode of elephant evolution using mastodon as outgroup. PLoS. Biol. 5: e207.

Saitoh R., Kawakami S., Asakawa M. 2004: The record of 3 species of parasitic helminthes and Eimeria (Protozoa: Eimeriidae) obtained from the Cape hyraxes (Procavia capensis) in Japan. Jpn. J. Zoo Wildl. Med. 9: 115-118.

SChmidt G.D., Wertheim G. 1988: Inermicapsifer beveridgei n. sp. (Cestoidea: Anoplocephalidae) from Procavia capensis (Hyracoidea) in Israel, with notes on two species of Hymenolepis. J. Parasitol. 74: 487-488.

SEIFFERT E.R. 2007: A new estimate of afrotherian phylogeny based on simultaneous analysis of genomic, morphological, and fossil evidence. BMC Evol. Biol. 7: 224.

Shoshani J. 2005: Order hyracoidean. In D.E. Wilson, D.M. Reeder (Eds), Mammal Species of the World. Johns Hopkins University Press, Baltimore, pp. 87-88.

Skinner J.D., Chimimba C.T. 2005: The Mammals of the Southern African Subregion, the third edition. Cambridge University Press, Cape Town, 814 pp.

Springer M.S., Murphy W.J., Eizirik E., O'Brien S.J. 2003: Placental mammal diversification and the Cretaceous-Tertiary boundary. Proc. Natl. Acad. Sci. USA. 100: 1056-1061.

StÖver B.C., Müller K.F. 2010: TreeGraph 2: combining and visualizing evidence from different phylogenetic analyses. BMC Bioinformatics. 11: 7

Upton S.J., Odell D.K., Bossart G.D., Walsh M.T. 1989: Description of the oocysts of two new species of Eimeria (Apicomplexa: eimerüdae) from the Florida manatee, Trichechus manatus (Sirenia: Trichechidae). J. Protozool. 36: 87-90.

Van den Berghe L., Chardome M. 1953: Eimeria dendrohyracis n. sp. chez les Damans du Kivu. Rev. Zool. Bot. Afr. 48: 292-294.

Van den Berghe L., Chardome M. 1962: Eimeria dorsalisi n. sp. chez le Daman arboricole Dendrohyrax dorsalis emini (Thomas). Rev. Zool. Bot. Afr. 65: 232-234.

Yabsley M.J., Gibbs S.E.J. 2006: Description and phylogeny of a new species of Eimeria from double-crested cormorants (Phalacrocorax auritus) near Fort Gaines, Georgia. J. Parasitol. 92: 385-388.

Zhao X., Duszynski D.W., Loker E.S. 2001: A simple method of DNA extraction for Eimeria species. J. Microbiol. Methods 44: $131-137$.

Cite this article as: Mohammed O.B., Aljedaie M.M., Alyousif M. S., Amor N. 2020: Eimeria tamimi sp. n. (Apicomplexa: Eimeriidae) from the rock hyrax (Procavia capensis jayakari) in central Saudi Arabia. Folia Parasitol. 67: 001. 